\title{
Analysis of the Content of Published Articles in the Journal Sport Mont in 2006
}

\author{
Marina Vukotic \\ University of Montenegro, Faculty for Sport and Physical Education, Niksic, Montenegro
}

\begin{abstract}
A B S T R A C T
The Montenegrin Sports Academy organized in 2006, the Second Congress and the Third Scientific Conference, with the international editorial and reputation, published by Sport Mont, 4(10-11). In this issue of the magazine there are 103 scientific papers from different multidisciplinary and monodisciplinary fields. The papers are classified by sports disciplines: training and testing, of multidisciplinary impact, kinematics, physiology of sport, sports history, sports sciences, sports psychology, sports medicine, sports management, sports equipment and technology, physical education and methodology, sports recreation, corrective gymnastics and anthropometry. In this paper we classified works by field, method of addressing analysis and found that the most numerous works from training and testing and multidisciplinary influence. We found that the published works had different themes of different multidisciplinary and monodisciplinary areas. Cited works can also be useful for further theoretical research, as they indicate the summing up of experiences and pointing to professional-scientific knowledge of practice and theory, and thus a wider view of the vital issues of sport, and of its overall achievements within the most current scientific fields.
\end{abstract}

Key words: Analysis, Sport Mont, Montenegrin Sports Academy, Montenegro

\section{Uvod}

Crnogorska sportska akademija organizovala je 2006. godine, Drugi kongres i Treću naučnu konferenciju, kada je, sa međunarodnom redakcijom i reputacijom, objavljen časopis „Sport Mont", 4(10-11). Sport Mont je zvanični časopis Crnogorske sportske akademije (CSA). Publikovani radovi su rezultati empirijskog ili teorijskog naučnog istraživanja, koji koriste naučne metode. U ovom broju časopisa ima 103 naučna rada iz različitih multidisciplinarnih i monodisciplinarnih oblasti, koji su podijeljeni u tri cjeline, i to: nove tehnologije u sportu, metodologija rada u sportu i društveno ekonomski odnosi u sportu. Naučni časopis "Sport Mont" ukazuje na sumiranje iskustava i na stručno-naučna saznanja prakse i teorije, a samim tim i šire sagledavanje vitalnih pitanja sporta, te njegovih ukupnih dostignuća u okviru najaktuelnih ekonomsko-društvenih, programskih, kadrovskih, organizaciono statusnih, materijalno-finansijskih i drugih razvojnih pitanja.

Časopis "Sport Mont" sastoji se originalnih recenziranih naučnih članaka i interdisciplinarnih prikaza istraživanja iz oblasti sportske nauke čiji su autori naučnici iz cijelog svijeta. Početak izlaženja publikacije bio je za uredništvo veoma težak, ali iz godine u godinu situacija se mijenjala, radovi koji su objavljeni bili sve kvalitetniji, pa se može reći da je časopis "Sport Mont" dospio do visokog nivoa u svijetu nauke. Postao je vodeća asocijacija sportskih naučnika na nivou Crne Gore, koja održava široku saradnju sa sličnim asocijacijama iz inostranstva. Svrha časopisa je promocija nauke i istraživanja, sa posebnom pažnjom posvećenom sportskoj nauci širom Crne Gore i izvan nje.

\section{Metod}

Analiza sadržaja je metoda koja je često prisutna u medijskim istraživanjima, a koja sistematizuje obimne komunikacije, pa se zbog otkrivanja velikog broja tema prilikom obrade podataka koriste statističke metode zbrajanja i deskripcije. Jedinica analize sadržaja su naslovi naučnih radova objavljenih u časopisu "Sport Mont", 4(10-11). U pomenutom časopisu su objavljena 103 rada. Radovi su klasifikovani po oblastima sportskih nauka: trening i testiranje, multidisciplinarani uticaj, kinematika, fiziologija sporta, istorija sporta, socijologija sporta, psihologija sporta, sportska medicina, sportski menadžment, sportska oprema i tehnologija, fizičko obrazovanje i metodika, sportska rekreacija, korektivna gimnastika i antropometrija.

\section{Rezultati}

U svim objavljenim naučnim radovima izvršena je analiza zbrajanja i deskripcije u procentima i prikazana tabelarno za sve naučne oblasti.

U svrhu optimizacije treninga važno je izvršiti testiranje i na taj način imati uvid $\mathrm{u}$ aktuelno stanje relevantnih sposobnosti, osobina i znanja sportista, kao i uvid u specifične zahtjeve pojedinog sporta ili sportske discipline. Trening je složen, programiran i kontrolisan postupak razvoja i održavanja brojnih sposobnosti sportiste ili sportskog tima. Radovi iz ove oblasti su: "Sistematizacija sportova i sportskih disciplina" (Bjelica, 2006), „Metode učenja u procesu sportskog treninga“ (Bjelica, 2006), „Efekti različitog modela plivačkog treninga usmjerenih na poboljšanje funkcionalnih sposobnosti“ (Krivokapić, 2006), „Program stretching-a za potrebe treninga rukometaša“ (Mavrić, 2006), „Profilaktičko dejstvo u procesu intezivnog treninga borilačkih sportova“ (Ćirković \& Kasum, 2006 ), „Uporedna analiza vrijednosti operatora treninga kod plivača Crne Gore i Vojvodine” (Radulović \& Goranović, 2006), "Informacioni pristup trenažnom procesu” (Plojović, 2006), „Novokonstruisani testovi za procjenu repetitivne snage džudista“ (Kopas, 2006), 
„Primjena eks testa u sportskom praksisu“ (Nemec, 2006), „Dijagnostički karate testovi“ (Doder, 2006), „Povezanost eksplozivne snage donjih ekstremiteta sa rezultatima testova za procenu agilnosti kod mladih košarkaša“ (Fratrić, 2006), „Pouzdanost nekih testova specifičnih motoričkih sposobnosti u džudou“ (Drid, 2006), ,Situacioni testovi iz orijentiringa u funkciji predikcije uspeha pripadnika policije u terenskoj obuci iz topografije“" (Milojković \& Dopsaj, 2006), "Instrument za procjenu sportsko-tehničkog obrazovanja iz košarke“ (Martinović,
2006), „Razlike u preformansama situacijske efikasnosti između juniora i juniorki sa svjetskog prvenstva u džudou-Tunis, 2000.godine" (Kajmović \& Kapo, 2006), "Strukturalna analiza sadržaja kondicione pripreme u džudou“ (Obadov, 2006), „Pokazatelji maksimalne sile pregibača lijeve i desne šake u funkciji selekcionog kriterijuma za potrebe policije“ (Dospaj, 2006), i „Analiza relacija džudo tehnika i specifične motorike“ (Drid, 2006).

Tabela 1. Analiza zbrajanja i deskripcije radova iz časopisa Sport Mont

\begin{tabular}{|c|c|c|c|c|}
\hline $\begin{array}{c}\text { Naučna } \\
\text { oblast }\end{array}$ & Autor & Naziv rada & $\begin{array}{l}\text { Broj } \\
\text { radova }\end{array}$ & $\%$ \\
\hline \multirow{22}{*}{$\begin{array}{l}\text { Trening i } \\
\text { testiranje }\end{array}$} & Bjelica, D. & Sistematizacija sportova i sportskih disciplina; & & \\
\hline & Bjelica, D. & Metode učenja u procesu sportskog treninga; & & \\
\hline & Krivokapić, D. & $\begin{array}{l}\text { Efekti različitog modela plivačkog treninga usmjereni na poboljšanje } \\
\text { funkcionalnih sposobnosti; }\end{array}$ & & \\
\hline & Mavrić, F. & Program stretchinga-a za potrebe treninga rukometaša; & & \\
\hline & Ćirković, Z. i & Profilaktičko dejstvo u procesu intezivnog treninga borilačkih spor- & & \\
\hline & Kasum, G. & tova; & & \\
\hline & Radulović, B. i & Uporedna analiza vrijednosti operatora treninga kod plivača Crne & & \\
\hline & Goranović, K. & Gore i Vojvodine; & & \\
\hline & Plojović, Š. & Informacioni pristup trenažnom procesu; & & \\
\hline & Kopas, J. & Novokonstruisani testovi za procjenu repetitivne snage džudista; & & \\
\hline & Nemec, $P$. & Primjena eks testa u sportskom praksisu; & \multirow{12}{*}{19} & \multirow{12}{*}{18.45} \\
\hline & Doder, D. & Dijagnostički karate testovi; & & \\
\hline & Fratić, F. & $\begin{array}{l}\text { Povezanost eksplozivne snage donjih ekstremiteta sa rezultatima te- } \\
\text { stova za procenu agilnosti kod mladih košarkaša; }\end{array}$ & & \\
\hline & Drid, P. & Program strechting-a za potrebe treninga rukometaša; & & \\
\hline & Milojković, B. i & Pouzdanost nekih testova specifičnih motoričkih sposobnosti u džu- & & \\
\hline & Dospaj, M. & dou; & & \\
\hline & Martinović, D. & $\begin{array}{l}\text { Situacioni testovi iz orijentiringa u funkciji predikcije uspeha pripad- } \\
\text { nika policije u terenskoj obuci iz topografije; }\end{array}$ & & \\
\hline & $\begin{array}{l}\text { Kajmović, H. i } \\
\text { Kapo, S. }\end{array}$ & Instrument za procjenu sportsko-tehničkog obrazovanja iz košarke; & & \\
\hline & & $\begin{array}{l}\text { Razlike u preformancama situacijske efikasnosti između juniora i ju- } \\
\text { niorki sa svjetskog prvenstva u džudou-tunis, 2000.godine; }\end{array}$ & & \\
\hline & Obadov, S. & Struktralna analiza sadržaja kondicione pripreme u džudou; & & \\
\hline & Dospaj, M. & $\begin{array}{l}\text { Pokazatelji maksimalne sile pregibača leve i desne šake u funkciji } \\
\text { selekcionog kriterijuma za potrebe policije; }\end{array}$ & & \\
\hline & Drid, P. & Analiza relacija džudo tehnika i specifične motorike. & & \\
\hline
\end{tabular}

Multidisciplinarani uticaj je okupljanje svih relevantih naučnih činilaca za određeno područje, a teme iz ove oblasti objavljene u časopisu "Sport Mont” su: „Uticaj motoričkih i morfoloških faktora na realizaciju elemenata akrobatike u nastavi fizičkog vaspitanja“ (Idrizović, 2006), „Relacije motoričkih i sitaciono-motoričkih sposobnosti u košarkaškoj igri“" (Mirvić, 2006), „Značaj fizičke sposobnosti i tehničke pripreme za razvoj mladih fudbalera“ (Raičković, 2006), „Razlike u morfološkim karakteristikama i motoričkim sposobnostima učenika i učenica drugog razreda osnovne škole“ (Zrnzević, 2006), „Razlike u morfološkim karakteristikama i funkcionalnim sposobnostima žena rekreativaca i neaktivnih žena" (Mladenović \& Nikolić, 2006), „Utjecaj motoričkih sposobnosti i konativnih regulativnih mehanizama na rezultatsku uspješnost u sportskim igrama“ (Ražanica, 2006), „Uticaj motoričkih vježbi na bazični motorički status džudista“" (Obadov, 2006), „Uticaj motoričkih sposobnosti i konativnih regulativnih mehanizama na situaciono-motoričke sposobnosti u košarci“ (Ražanica, 2006), „Uticaj konativnih karakteristika na rezultatsku uspješnost u nekim sportskim igrama kod učenica srednje škole“ (Mirvić, 2006), „Razvoj dinamičke snage primjenom rada po "stanicama" (Stojiljković, 2006), „Bazična motorika fudbalera i nesportista predpubertetskog uzrasta“ (Janković, 2006), i „Uticaj morfoloških karakteristika na preciznost ubacivanja lopte u koš kod košarkaša pionirskog uzrasta“" (Nikolić, 2006).

Kinematika je opisivanje mehanizama organizacije, iniciranja i realizacije pokreta, njihovu eksplikaciju i formiranje modela, čijom se simulacijom može predvidjeti ponašanje realnog kinetičkog sistema u datim uslovima. Radovi iz ove oblasti su: „Uticaj kinematičkih strukturalnih elemenata pri formiranju oblika krivulje kod sprintera u trčanju na 100 m“ (Jovović, 2006), „Povezanost koluta naprijed i koluta nazad sa motoričkim sposobnostima učenika V razreda“ (Petković, 2006), „Komparacija tehničko - taktičkih karate elemenata između učesnica međunarodnog karate turnira "Sarajevo open" (Kapo \& Kajmović, 2006), „Uticaj eksperimentalnog rada na poboljšanju brzinske izdržljivosti, kod studenata fakulteta za fizičku kulturu u Leposaviću“ (Stefanović, 2006), „Uticaj bazične motorike na snagu udarca po lopti nogom i glavom u nogometnoj igri“ (Mekić \& Hadžić, 2006), „Gimnastički preskoci i njihova povezanost sa motoričkim sposobnostima učenika V razreda“ (Marušić \& Petković, 2006), „Uticaj antropometrijskih karakteristika i funkcionalnih sposobnosti na bočnu i dubinsku pokretljivost rukometaša" (Mavrić, 2006), "Procjena uticaja kružnog oblika rada na 
razvoj brzine u nastavi fizičkog vaspitanja“ (Milošević, 2006), „Prediktivna vrijednost motoričkih manifestacija u odnosu na preskoke kao programske sadržaje u nastavi fizičkog vaspitanja“ (Idrizović, 2006), „Uticaj osnovne obuke u gađanju realizovane po modelu međunarodnih standarda na efikasnost pri upotrebi pištolja kod žena policajaca“ (Vučković, 2006), „Metodika učenja karving tehnike u alpskom skijanju“ (Hadžić, 2006), i ,Transformacija različitih vrsta energije jedne u drugu $i$ mjerenje njihovih efekata kod izvođenja skoka motkom" (Jovović, 2006).

Tabela 2. Analiza zbrajanja i deskripcije radova iz časopisa Sport Mont

\begin{tabular}{|c|c|c|c|c|}
\hline Naučna oblast & Autor & Naziv rada & $\begin{array}{c}\text { Broj } \\
\text { radova }\end{array}$ & $\%$ \\
\hline \multirow{12}{*}{$\begin{array}{l}\text { Multidisciplinarni } \\
\text { uticaj }\end{array}$} & Idrizović, K. & $\begin{array}{l}\text { Uticaj motoričkih i morfoloških faktora na realizaciju eleme- } \\
\text { nata akrobatike u nastavi fizičkog vaspitanja; }\end{array}$ & \multirow{12}{*}{13} & \multirow{12}{*}{12.62} \\
\hline & Mirvić, E. & $\begin{array}{l}\text { Relacije motoričkih i sitaciono-motoričkih sposobnosti u ko- } \\
\text { šarkaškoj igri; }\end{array}$ & & \\
\hline & Raičković, N. & $\begin{array}{l}\text { Značaj fizičke sposobnosti i tehničke pripreme za razvoj mla- } \\
\text { dih fudbalera; }\end{array}$ & & \\
\hline & Zrnzević, N. & $\begin{array}{l}\text { Razlike u morfološkim karakteristikama i motoričkim sposob- } \\
\text { nostima učenika i učenica drugog razreda osnovne škole; }\end{array}$ & & \\
\hline & $\begin{array}{l}\text { Mladenović, I. i } \\
\text { Nikolić, M. }\end{array}$ & $\begin{array}{l}\text { Razlike u morfološkim karakteristikama i funkcionalnim spo- } \\
\text { sobnostima žena rekreativaca i neaktivnih žena; }\end{array}$ & & \\
\hline & Ražanica, F. & $\begin{array}{l}\text { Uticaj motoričkih sposobnosti i konativnih regulativnih meha- } \\
\text { nizama na rezultatsku uspješnost u sportskim igrama; }\end{array}$ & & \\
\hline & Obadov, S. & Uticaj motoričkih vježbi na bazični motorički status džudista; & & \\
\hline & Ražanica, F. & $\begin{array}{l}\text { Uticaj motoričkih sposobnosti i konativnih regulativnih meha- } \\
\text { nizama na situaciono-motoričke sposobnosti u košarci; }\end{array}$ & & \\
\hline & Mirvić, E. & $\begin{array}{l}\text { Uticaj konativnih karakteristika na rezultatsku uspješnost u ne- } \\
\text { kim sportskim igrama kod učenica srednje škole; }\end{array}$ & & \\
\hline & Stojiljković, S. & Razvoj dinamičke snage primjenom rada po "stanicama; & & \\
\hline & Janković, I. & $\begin{array}{l}\text { Bazična motorika fudbalera i nesportista predpubertetskog uz- } \\
\text { rasta; }\end{array}$ & & \\
\hline & Nikolić, I. & $\begin{array}{l}\text { Uticaj morfoloških karakteristika na preciznost ubacivanja lop- } \\
\text { te u koš kod košarkaša pionirskog uzrasta. }\end{array}$ & & \\
\hline
\end{tabular}

Fiziologija sporta proučava organizam i njegove funkcije tokom fizičkih aktivnosti, a radovi iz ove oblasti su: „Uticaj intezivne fizičke aktivnosti na proces lipidne peroksidacije i antioksidativno dejstvo askorbinske kisjeline“" (Stefanović, 2006), „Kvantitativne promjene funkcionalnih i brzinskih sposobnosti vaterpolista kadeta u pripremnom i takmičarskom periodu“" (Janković \& Aleksandrović, 2006), „Metrijske karakteristike pojedinih testova za procjenu aerobnih i anerobnih sposobnosti“ (Branković \& Stojiljković, 2006), „Frekvencija pulsa kao indikator opterećenja u sportskoj rekreaciji“ (Goranović \& Radulović, 2006), “ Uticaj programiranog plivanja na respiratorni status“" (Madić \& Okićić, 2006), „Funkcionalne sposobnosti učenika-sportista timskih sportova i neportista“ (Jonić \& Aleksandrović, 2006), „Uticaj nadmorske visine na fiziološko-funkcionalne sposobnosti studenata" (Koničanin \& Bronja, 2006), i „Hodanje-pješačenje u funkciji osnovnih aktivnosti u fitness-u“ (Bijelić, 2006).

U časopisu "Sport Mont" zastupljeni su radovi iz fizičkog obrazovanja i metodike, i to: „Relacije između postignuća u nastavi fizičkog vaspitanja i morfoloških karakteristika" (Martinović, 2006), „Samoodbrana sa metodikom izvođenja“ (Radović, 2006), „Prirodni oblici kretanja kao osnova motoričkog razvoja predškolskog uzrasta“ (Šabotić, 2006), „Značaj i uloga poligona u razvoju biomotoričkih znanja učenika I ciklusa devetogodišnje osnovne škole“ (Milošević, 2006), „Efikasnost različitih metodičkih modela učenja plivanja djece predškolskog uzrasta“" (Krivokapić, 2006), „Realizacija programskih sadržaja u nastavi fizičkog vaspitanja u drugom razredu osnovne škole na bazi minimalnih zahteva“ (Zrnzević, 2006), „Efikasnost i postignuća u nastavi fizičkog vaspitanja u okvirima najnovijih reformi“" (Šekeljić \& Stamatović, 2006), „Integrativni pristup nastavi u prirodi kao savremenoj pedagoškoj inicijativi“" (empirijsko istraživanje sa osvrtom na fizičko vaspitanje)“ (Međedović \& Međedović, 2006), „Mišljenja i stavovi razrednih učitelja prema vrednovanju (evaluaciji) i ocenjivanju u nastavi fizičkog vaspitanja“ (Međedović, 2006), „Stavovi srednjoškolaca prema vrijednostima nastave fizičkog vaspitanja“ (Kljajević, 2006), „Rukomet kao izborni predmet u III ciklusu devetogodišnje osnovne škole“ (Marušić, 2006).

Antropometrija je metoda koja obuhvata mjerenje ljudskog tijela, te obradu i proučavanje dobijenih mjera „Validnost testova skočnosti“ (Opavsky, 2006), „Antropometrijske karakteristike fudbalera, košarkaša i odbojkaša“" (Bronja \& Konicanin, 2006), i „Uticaj prediktorskog sistema varijabli antropološkog statusa na uspješnost prve etape bazične selekcije u sportskoj gimnastici kod devojčica“" (Mekić \& Petković, 2006).

Korektivna gimnastika predstavlja skup fizičkih vježbi doziranih po intezitetu, vrsti i trajanju, koje se mogu primenjivati preventivno kod djece koja imaju predispozicije za nastanak nekog od posturalnih deformiteta ili terapijski ako oni već postoje, 
a radovi su: „Utvrđivanje deformiteta kičmenog stuba kod učenika u srednjoj školi "Ivan Goran Kovačević" u Herceh Novi“
(Bejković \& Đorđe, 2006), i "Igra kao metod korektivnog vježbanja djece predškolskog uzrasta“"(Bejković, 2006).

Tabela 3. Analiza zbrajanja i deskripcije radova iz časopisa Sport Mont

\begin{tabular}{|c|c|c|c|c|}
\hline $\begin{array}{l}\text { Naučna } \\
\text { oblast }\end{array}$ & Autor & Naziv rada & $\begin{array}{c}\text { Broj } \\
\text { radova }\end{array}$ & $\%$ \\
\hline \multirow{15}{*}{ Kinematika } & Jovović, V. & $\begin{array}{l}\text { Uticaj kinematičkih strukturalnih elemenata pri formiranju oblika } \\
\text { krivulje kod sprintera u trčanju na } 100 \mathrm{~m} \text {; }\end{array}$ & \multirow{15}{*}{12} & \multirow{15}{*}{11.65} \\
\hline & Petković, J. & $\begin{array}{l}\text { Povezanost koluta naprijed i koluta nazad sa motoričkim sposob- } \\
\text { nostima učenika V razreda; }\end{array}$ & & \\
\hline & Kapo,S. i & Komparacija tehničko - taktičkih karate elemenata između uče- & & \\
\hline & Kajmović, $\mathrm{H}$. & snica međunarodnog karate turnira "Sarajevo open"; & & \\
\hline & Stefanović, R. & $\begin{array}{l}\text { Uticaj eksperimentalnog rada na poboljšanju brzinske izdržljivo- } \\
\text { sti, kod studenata fakulteta za fitičku kulturu u Leposaviću: }\end{array}$ & & \\
\hline & Mekić, M. i & Uticaj bazične motorike na snagu udarca po lopti nogom i gla- & & \\
\hline & Hadžić, R. & vom u nogometnoj igri; & & \\
\hline & Marušić, R. i & Gimnastički preskoci i njihova povezanost sa motoričkim spo- & & \\
\hline & Petković, J. & sobnostima učenika v razreda; & & \\
\hline & Marvić, F. & $\begin{array}{l}\text { Uticaj antropometrijskih karakteristika i funkcionalnih sposobno- } \\
\text { sti na bočnu i dubinsku pokretljivost rukometaša; }\end{array}$ & & \\
\hline & Milošević, B. & $\begin{array}{l}\text { Procjena uticaja kružnog oblika rada na razvoj brzine u nastavi } \\
\text { fizičkog vaspitanja; }\end{array}$ & & \\
\hline & Idrizović, $\mathrm{K}$. & $\begin{array}{l}\text { Prediktivna vrijednost motoričkih manifestacija u odnosu na pre- } \\
\text { skoke kao programske sadržaje u nastavi fizičkog vaspitanja; }\end{array}$ & & \\
\hline & Vučković, I. & $\begin{array}{l}\text { Uticaj osnovne obuke u gađanju realizovane po modelu međuna- } \\
\text { rodnih standarda na efikasnost pri upotrebi pištolja kod žena poli- } \\
\text { cajaca; }\end{array}$ & & \\
\hline & Hadžić, R. & Metodika učenja karving tehnike u alpskom skijanju; & & \\
\hline & Jovović, V. & $\begin{array}{l}\text { Transformacija različitih vrsta energije jedne u drugu i mjerenje } \\
\text { njihovih efekata kod izvođenja skoka motkom. }\end{array}$ & & \\
\hline \multirow{12}{*}{$\begin{array}{l}\text { Fiziologija } \\
\text { sporta }\end{array}$} & Stefanović, R. & $\begin{array}{l}\text { Uticaj intezivne fizičke aktivnosti na proces lipidne peroksidacije } \\
\text { i antioksidativno dejstvo askorbinske kisjeline; }\end{array}$ & \multirow{12}{*}{8} & \multirow{12}{*}{7.77} \\
\hline & Janković, V i & Kvantitativne promjene funkcionalnih i brzinskih sposobnosti va- & & \\
\hline & Aleksandrović, M. & terpolista kadaeta u pripremnom i takmičarskom periodu; & & \\
\hline & Branković, N. i & Metrijske karakteristike pojedinih testova za procjenu aerobnih i & & \\
\hline & Stojiljković, S. & anerobnih sposobnosti; & & \\
\hline & Goranović, K. i & Frekvencija pulsa kao indikator opterećenja u sportskoj rekreaci- & & \\
\hline & Radulović, B. & & & \\
\hline & Madić, D i & Uticaj programiranog plivanja na respiratorni status & & \\
\hline & Okičić, T. & $\begin{array}{l}\text { Funkcionalne sposobnosti učenika-sportista timskih sportova i } \\
\text { neportista: }\end{array}$ & & \\
\hline & Koničanin, A. i & Uticaj nadmorske visine na fiziološko-funkcionalne sposobnosti & & \\
\hline & Bronja, A. & studenata; & & \\
\hline & Bijelić, B. & Hodanje-pješačenje u funkciji osnovnih aktivnosti u fitness-u & & \\
\hline
\end{tabular}

Iz oblasti psihologije sporta, sociologije sporta i istorije sporta u časopisu „Sport Mont“ zastupljeni su radovi: „Patološki konativni faktori u postranom periodu kod učenika srednjih škola“ (Mekić, 2006), „Self koncept kao bitan faktor uspjeha u sportu“ (Čokorilo, 2006), „Misterija šahovske igre“ (Drobnjak, 2006), „Komunikacije u sportu“ (Bjelica \& Maksimović, 2006), "Vrhunski sport ili nastavak školovanja" (Lepes \& Kobak, 2006), „Tip organizacije grupe u košarkaškim timovima 1. lige Srbije i Crne Gore“ (Vučković, 2006), „Kvalitet razvoja i usavršavanja u sportu kod mlađih uzrasnih kategorija"(Arsić, 2006), „Sport u 21. Veku“(Živanović \& Kafedžić, 2006), „Dileme i ideje vazane za slobodni stil rvanja u Srbiji i Crnoj Gori“ (Kasum, 2006), „Inicijative i predlozi za uvođenje nastave gimnastike u osnovne škole kneževine Srbije“(Mijatović, 2006), „Filozofija edukacije i sport“(Radoš, 2006), „Sokolstvo u Budvi i Petrovcu“(Klarić, 2006), i „Početak igranja tenisa kao podstrek razvoja sporta u Crnoj Gori“ (Rašović, 2006).

Iz oblasti sportskog menadžmenta objavljeni su radovi:
„Strategija menadžerskog upravljanja konfliktima u sportu“ (Dacić, 2006), „Trener-istraživač-menadžer“ (Nićin, 2006), „Motivacione determinante kadrova u karate sportu“ (Nešić, 2006), „Strategijski pristupi pormenama okruženja sportskih organitacija“" (Maksimović \& Milošević, 2006), „Menadžment sportskog događaja" mini olimpijske igre-Zemun 2004" (Šiljak, 2006), „Fandrejzing u sportu“ (Radović, 2006), „Sportsko novinarstvo i profesionalna etika: problem identiteta (Milošević, 2006), i „Sportsko sponzorstvo kao distinktivna kompetencija“ (Ljubojević \& Vetro).

U časopisu „Sport Mont“ iz oblasti sportske opreme i tehnologije su radovi: „Bežični pristup internetu za potrebe sporta“ (Marčićević, 2006), „Planinski bicikl-sredstvo za realizaciju treking tura“ (Martinović \& Branković, 2006), „Primjena informacionih tehnologija u sportu“(Plojović, 2006), i „Kako doći do vrhunskog rezultata“ (Kafedžić \& Kazazović, 2006). 
Tabela 4. Analiza zbrajanja i deskripcije radova iz časopisa Sport Mont

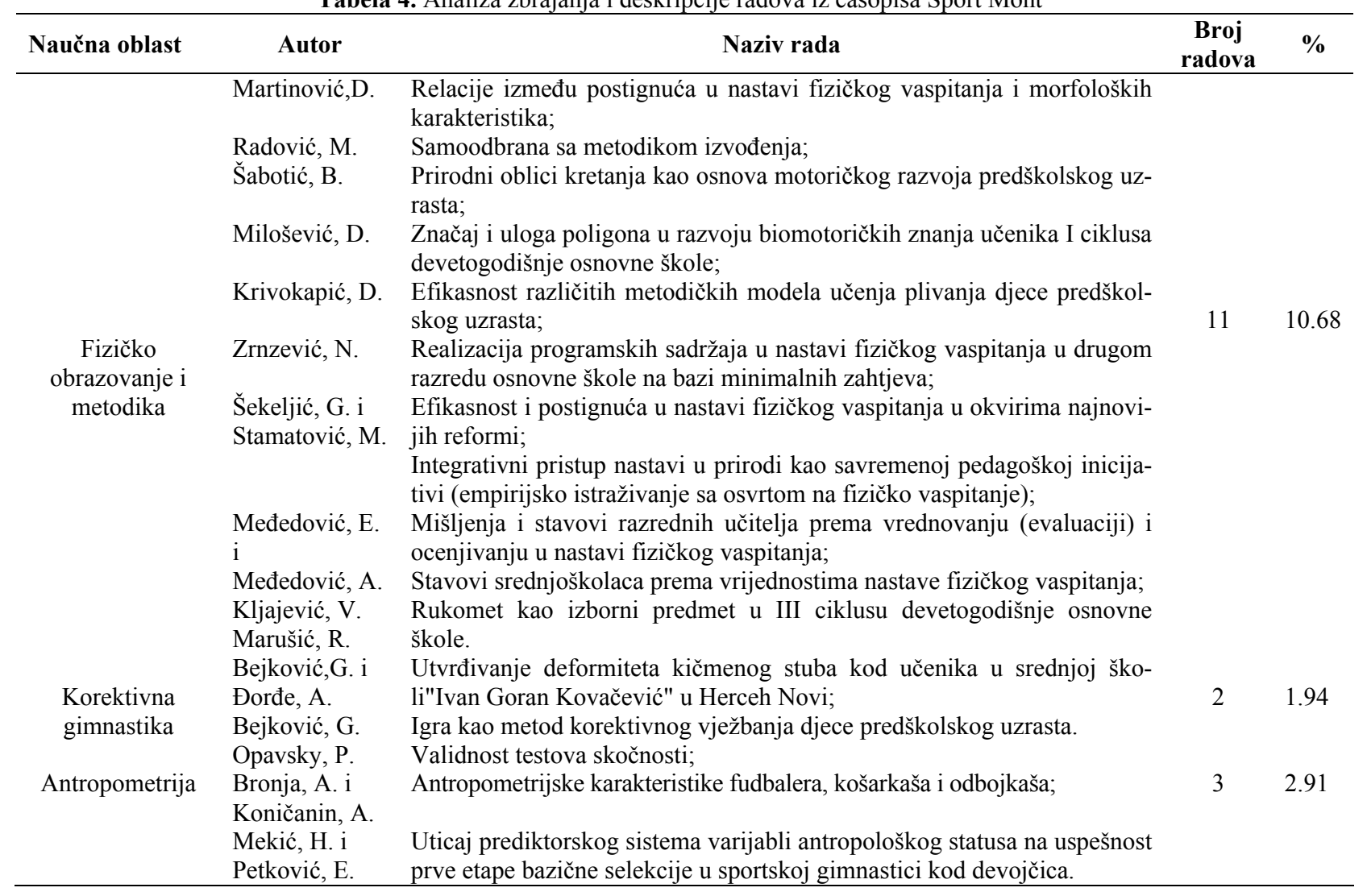

Sportska rekreacija je slobodno odabrana, a ne nametnuta aktivnost koja se pretežno sprovodi u slobodno vrijeme, mada iako je najvećim dijelom vezana za slobodno vrijeme, danas se sve češće pojavljuje u specifičnim programima kao značajan element savremene naučne organizacije rada i odmora. Radovi iz ove oblasti su: „Potrebe za valorizacijom efekata vježbanja u rekreaciji“ (Bijelić, 2006), „Banjsko-klimatski centri kao resurs implementacije programasportske rekreacije“ (Nikolić, 2006), i „Stavovi ispitanika prema primeni programa sportske rekreacije u turizmu“ (Nikolić, 2006).

Tabela 5. Analiza zbrajanja i deskripcije radova iz časopisa Sport Mont

\begin{tabular}{|c|c|c|c|c|}
\hline Naučna oblast & Autor & Naziv rada & $\begin{array}{c}\text { Broj } \\
\text { radova }\end{array}$ & $\%$ \\
\hline Istorija sporta & $\begin{array}{l}\text { Živanović, N. i } \\
\text { Kafedžić, E. } \\
\text { Kasum,G. } \\
\text { Mijatović, S. } \\
\text { Radoš, J. } \\
\text { Klarić, D. } \\
\text { Rašović, D. }\end{array}$ & $\begin{array}{l}\text { Sport u 21. veku; } \\
\text { Dileme i ideje vazane za slobodni stil rvanja u Srbiji i Crnoj } \\
\text { Gori; } \\
\text { Inicijative i predlozi za uvođenje nastave gimnastike u osnovne } \\
\text { škole kneževine Srbije; } \\
\text { Filozofija edukacije i sport; } \\
\text { Sokolstvo u Budvi i Petrovcu; } \\
\text { Početak igranja tenisa kao podstrek razvoja sporta u Crnoj Gori }\end{array}$ & 6 & 5.83 \\
\hline $\begin{array}{c}\text { Socijologija } \\
\text { sporta }\end{array}$ & $\begin{array}{l}\text { Bjelica, S. i } \\
\text { Maksimovć, N. } \\
\text { Vučković, G. } \\
\text { Arsić, M. }\end{array}$ & $\begin{array}{l}\text { Komunikacije u sportu; } \\
\text { Vrhunski sport ili nastavak školovanja; } \\
\text { Tip organizacije grupe u košarkaškim timovima lige Srbije i Cr- } \\
\text { ne Gore; } \\
\text { Kvalitet razvoja i usavršavanja u sportu kod mlađih uzrasnih ka- } \\
\text { tegorija. }\end{array}$ & 4 & 3.88 \\
\hline $\begin{array}{c}\text { Psihologija } \\
\text { sporta }\end{array}$ & $\begin{array}{l}\text { Mekić, M. } \\
\text { Čokorilo, R. } \\
\text { Drobnjak, D. }\end{array}$ & $\begin{array}{l}\text { Patološki konativni faktori u postranom periodu kod učenika } \\
\text { srednjih škola; } \\
\text { Self koncept kao bitan faktor uspjeha u sportu; } \\
\text { Misterija šahovske igre. }\end{array}$ & 3 & 2.91 \\
\hline
\end{tabular}


Sportska medicina je oblast zdravstva koja primenjuje medicinu i nauku u sprečavanju, prepoznavanju, liječenju, i rehabilitaciji povreda izazvanih sportom i vježbanjem. Radovi iz oblasti sportske medicine su: „Uticaj eksperimentalnog krostretmana pri banjskom lečenju funkcionalnih neurotičnih bolesti“ (Stefanović, 2006), „Iznenadna smrt sportista“ (Femić \& Stanišić, 2006), „Uloga tai či čuana u očuvanju zdravlja, sprečavanja i lečenja bolesti“ (Mikalacki \& Čolorilo, 2006), „Funk- cionalno osposobljavanje fizikalni tretman povreda mišićnog tkiva kod fudbalera" (Joksimović, \& Joksimović, 2006), „Opravdanost i neopravdanost oslobađanja učenika od nastave fizičkog vaspitanja iz zdravstvenih razloga u osnovnoj školi“ (Femić \& Stanišić, 2006), "Razlike u stanju uhranjenosti žena rekreativaca i neaktivnih žena" (Mladenović \& Nikolić, 2006), i "Značaj nutrijenta u ishrani plivača" (Tomislav \& Madić, 2006).

Tabela 6. Analiza zbrajanja i deskripcije radova iz časopisa Sport Mont

\begin{tabular}{|c|c|c|c|c|}
\hline $\begin{array}{l}\text { Naučna } \\
\text { oblast }\end{array}$ & Autor & Naziv rada & Broj radova & $\%$ \\
\hline $\begin{array}{l}\text { Sportska } \\
\text { medicina }\end{array}$ & $\begin{array}{l}\text { Stefanović, R. } \\
\text { Femić, M. i } \\
\text { Stanišić, S. } \\
\text { Mikalački, M. i } \\
\text { Čokorilo, N. } \\
\text { Femić, M. i } \\
\text { Stanišić, S. } \\
\text { Mladenović, I. i } \\
\text { Nikolić, M. } \\
\text { Tomislav, O. i } \\
\text { Madić, D. }\end{array}$ & $\begin{array}{l}\text { Uticaj eksperimentalnog kros-tretmana pri banjskom lečenju } \\
\text { funkcionalnih neurotičnih bolesti; } \\
\text { Iznenadna smrt sportista; } \\
\text { Uloga tai či čuana u očuvanju zdravlja, sprečavanja i leče- } \\
\text { nja bolesti; } \\
\text { Funkcionalno osposobljavanje fizikalni tretman povreda mi- } \\
\text { šćnog tkiva kod fudbalera; } \\
\text { Opravdanost i neopravdanost oslobađanja učenika od nasta- } \\
\text { ve fizičkog vaspitanja iz zdravstvenih razloga u osnovnoj } \\
\text { školi; } \\
\text { Razlike u stanju uhranjenosti žena rekreativaca i neaktivnih } \\
\text { žena; } \\
\text { Značaj nutrijenta u ishrani plivača. }\end{array}$ & 7 & 6.80 \\
\hline $\begin{array}{c}\text { Sportski } \\
\text { manadžment }\end{array}$ & $\begin{array}{l}\text { Dacić, R. } \\
\text { Nićin, D. } \\
\text { Nešić, M. } \\
\text { Maksimović, N. i } \\
\text { Milošević, Z. } \\
\text { Radović, M. } \\
\text { Milošević, B. } \\
\text { Ljubojević, C. i } \\
\text { Vetro, L. }\end{array}$ & $\begin{array}{l}\text { Strategija menadžerskog upravljanja konfliktima u sportu; } \\
\text { Trener-istraživač.menadžer; } \\
\text { Motivacione determinante kadrova u karate sportu; } \\
\text { Strategijski pristupi pormenama okruženja sportskih organi- } \\
\text { tacija; } \\
\text { Menadžment sportskog događaja"mini olimpijske igre-ze- } \\
\text { mun 2004"; } \\
\text { Fandrejzing u sportu; } \\
\text { Sportsko novinarstvo i profesionalna etika:problem identite- } \\
\text { ta; } \\
\text { Sportsko sponzorstvo kao distinktivna kompetencija }\end{array}$ & 8 & 7.77 \\
\hline $\begin{array}{l}\text { Sportska opre- } \\
\text { ma i tehnolo- } \\
\text { gija }\end{array}$ & $\begin{array}{l}\text { Marčićević, Z. } \\
\text { Martinović, D. i } \\
\text { Branković, D. } \\
\text { Plojović, S. } \\
\text { Kafedžić,E. i } \\
\text { Kazazović, B. } \\
\text { Bijelić, B. } \\
\text { Nikolić, I. } \\
\text { Nikolić, I. }\end{array}$ & $\begin{array}{l}\text { Bežični pristup internetu za potrebe sporta; } \\
\text { Planinski bicikl-sredstvo za realizaciju treking tura; } \\
\text { Primjena informacionih tehnologija u sportu,; } \\
\text { Kako doći do vrhunskog rezultata; } \\
\text { Potrebe za valorizacijom efekata vježbanja u rekreaciji; } \\
\text { Banjsko-klimatski centri kao resurs implementacije progra- } \\
\text { masportske rekreacije; } \\
\text { Stavovi ispitanika prema primeni programa sportske rekrea- } \\
\text { cije u turizmu. }\end{array}$ & 4 & 3.88 \\
\hline
\end{tabular}

\section{Diskusija}

U ovom radu smo klasifikovali teme iz časopisa „Sport Mont" po oblastima, metodom analize utvrđeno je koje teme imaju najsvremenije tedencije u sportskoj nauci. Istaći ćemo procentualno (103) rada po naučnim oblastima, i to trening i testiranje 18.45, multidisciplinarni uticaj 12.62, kinematika 11.65 , fiziologija sporta 7.77 , korektivna gimnastika 1.94 , antropometrija 2.91 , sportski menadžment 7.77 , sportska oprema i tehnologija 3.88 , fizičko obrazovanje i metodika 10.86 , sportska rekreacija 2.91, istorija sporta 5.83 , sociologija sporta 3.88 , psihologija sporta 2.91, od od ukupnog broja objavljenih radova u pomenutom časopisu. Radovi iz treninga i testiranja i multidisciplinarnog uticaja su najcitiraniji i najbolje kotirani. Na osnovu navedenog, možemo istaći i razlog napredovanja časopisa.
Utvrdili smo da su publikovani radovi imali raznovrsne teme različitih multidisciplinarnih i monodisciplinarnih oblasti. Klasifikovani radovi mogu biti korisni i za dalja teorijska istraživanja, jer ukazuju na sumiranje iskustava i na stručno-naučna saznanja prakse i teorije, a samim tim i šire sagledavanje vitalnih pitanja sporta, te njegovih ukupnih dostignuća u okviru najaktuelnih naučnih oblasti.

Godišnje konferencije se organizuju od samog osnivanja Crnogorske sportske akademije. Danas se konferencija Crnogorske sportske akademije svrstava među vodeće sportske naučne kongrese na Zapadnom Balkanu. Konferencija uključuje niz gostujućih predavača, usmene i poster prezentacije iz multidisciplinarnih i monodisciplinarnih oblasti, kao i različite vrste radionica. Konferenciji prisustvuju nacionalni, regionalni i međunarodni sportski naučnici sa akademskim karijerama. Postig- 
nuti su preliminarni dogovori sa istaknutim stručnjacima iz zemlje i inostranstva oko angažovanja na projektu organizovanja stručnih savjetovanja, javnih rasprava i naučnih skupova iz ove oblasti.

Zaključujemo časopis „Sport Mont“ postao je vodeća asoci-

\section{R E F E R E N C E S}

Arsić, M. (2006). Kvalitet razvoja i usavršavanja u sportu kod mlađih uzrasnih kategorija. Sport Mont, IV (10-11), 638643.

Bijelić, B. (2006). Necessity to valorize training effects in recreation. Sport Mont, IV(10-11), 406- 412.

Bijelić, B. (2006). Walking in function of main fitness activities. Sport Mont, IV(10-11), 616- 621.

Bjeković, G. (2006). Play as a method of corrective exercise training in pre-school children. Sport Mont, IV(10-11), 460464.

Bjeković, G., \& Đorđe, A. (2006). Establishment of the state of spine deformity in students of the secondary school „IvanGoran Kovačić“", Herceg Novi. Sport Mont, IV(10-11), 8088.

Bjelica, D. (2006). Methods of learning in process of sports training. Sport Mont, IV(10-11), 198- 202.

Bjelica, D. (2006). Systematization of sports and sport disciplines according to the aspect of sport training. Sport Mont, IV (10-11), 440-445.

Bjelica, S., \& Maksimović, N. (2006). Communications in sport. Sport Mont, IV(10-11), 21-25.

Branković, N., \& Stojiljković, S. (2006). Metric characteristics of some tests for evaluation of aerobic and anaerobic capacities. Sport Mont, IV(10-11), 188-192.

Bronja, A., \& Koničanin, A. (2006). The football, basketball and volleyball player antrohometric characteristics. Sport Mont, IV(10-11), 334-344.

Ćirković, Z., \& Kasum, G. (2006). Prophylaxical effect at the intensive training process af combat sports. Sport Mont, IV(10-11), 276-284.

Čokorilo, R., \& Tišma, M. (2006). Self-concept as an important factor of sports success.Sport Mont, IV(10-11), 315-320.

Dacić, R. (2006). Strategija menadžerskog upravljanja konfliktima u sportu. Sport Mont, IV(10-11), 131-135.

Doder, D. (2006). Diagnostic karate tests. Sport Mont, IV(1011), 101-107.

Dopsaj, M., \& Vučković, G. (2006). Indicators of maximal flexor force of left and right hand for the police selection criteria purposes. Sport Mont, IV(10-11), 148-154.

Drid, P. (2006). Analysis of relations between judo techniques and specific motor abilities. Sport Mont, IV(10-11), 114119.

Drid, P. (2006). Reliability of certain tests of specific motor abilities in judo. Sport Mont, IV(10-11), 243-247.

Drobnjak, D. (2006). Misterija šahovske igre. Sport Mont, IV(10-11), 659-664.

Femić, M., \& Stanišić, S. (2006). A sudden death of sportsmen. Sport Mont, IV(10-11), 181-187.

Femić, M., \& Stanišić, S. (2006). Opravdanost i neopravdanost oslobađanja učenika od nastave fizičkog vaspitanja iz zdravstvenih razloga u osnovnoj školi. Sport Mont, IV(1011), 634- 637.

Fratrić, F. (2006). Povezanost eksplozivne snage donjih ekstremiteta sa rezultatima testova za procenu agilnosti kod mladih košarkaša. Sport Mont, IV(10-11), 203-208.

Goranović, K., \& Radulović, B. (2006). Frequency of pulse as jacija sportskih naučnika na nivou Crne Gore, koja održava široku saradnju sa sličnim asocijacijama iz inostranstva. Svrha časopisa je promocija nauke $\mathrm{i}$ istraživanja, sa posebnom pažnjom posvećenom sportskoj nauci širom Crne Gore i izvan nje.

marker ballast in sportive recreation. Sport Mont, IV(1011), 193-197.

Hadžić, R. (2006). Teaching methodology of carving technikque in alpine sking. Sport Mont, IV(10-11), 360-366.

Idrizović, K. (2006). Impact of motoric and morphologic factors on realization of elements of acrobatics in the physical education instruction. Sport Mont, IV(10-11), 64-70.

Idrizović, K. (2006). Predictive value of motoric manifestations regarding vaults as programme contents in the physical education instruction. Sport Mont, IV(10-11), 293-299.

Janković, I., \& Jonić, Z. (2006). Basic mobility of football players and non-sportsmen at preadolescent age. Sport Mont, IV(10-11), 395-399.

Joksimović, V., \& Joksimović, M. (2006). Functional rehabilitation and physical treatment of muscle tissue injuries of football players. Sport Mont, IV(10-11), 583-589.

Jonić, Z., \& Aleksandrović, M. (2006). Functional abilities of schoolboys - team sportsmen and nonsportsmen. Sport Mont, IV (10-11), 354-359.

Jovović, V. (2006). The transformation of different types of energy one in an other and measuring of their effects during the pole vault. Sport Mont, IV(10-11), 144-147.

Jovović, V. (2006). Uticaj kinematičkih strukturalnih elemenata pri formiranju oblika krivulje kod sprintera u trčanju na 100 m. Herceg Novi. Sport Mont, IV(10-11), 89-94.

Kafedžić, E., \& Kazazović, B. (2006). Kako doći do vrhunskog rezultata. Sport Mont, IV(10-11), 510-515.

Kajmović, H., \& Kapo, S. (2006). Razlike u performancama situacijske efikasnosti između juniora i juniorki sa svjetskog prvenstva u džudou - Tunis, 2000. godine. Sport Mont, IV (10-11), 300-306.

Kapo, S., \& Kajmović, H. (2006). Komparacija tehničko - taktičkih karate elemenata između učesnica međunarodnog karate turnira "Sarajevo open" 2004. Sport Mont, IV(10-11), 126- 130.

Kasum, G. (2006). Dilemas and ideas connected with freestyling wrestling in Serbia and Montenegro. Sport Mont, IV (10-11), 465-471.

Klarić, D. (2006). Sokolstvo u Budvi i Petrovcu. Sport Mont, IV (10-11), 607-615.

Kljajević, V. (2006).Stavovi srednjoškolaca prema vrijednostima nastave fizičkog vaspitanja. Sport Mont, IV(10-11), 680-685

Koničanin, A., \& Bronja, A. (2006). Influence of the height above sea level to the phisiological-functional capabilites of the students. Sport Mont, IV(10-11), 367-374.

Kopas, J. (2006). Newly constructed tests for repetitive strength evaluation in judo. Sport Mont, IV(10-11), 55-63.

Krivokapić, D. (2006). The effects of the swimming training model aimed at the improvement of functional abilities. Sport Mont, IV(10-11), 173-180.

Krivokapić, D. (2006). Efficiency of different methodological models of swimming practice with pre-school children. Sport Mont, IV(10-11), 433-439.

Lepeš, J., \& Kabok, I. (2006). First-class sport or continuation education. Sport Mont, IV(10-11) 453-459. 
Ljubojević, C., \& Vetro, L. (2006). Sportsko sponzorstvo kao distinktivna kompetencija. Sport Mont, IV(10-11), 651-658.

Madić, D., \& Okičić, T. (2006). Influence of programmed swimming on swimmers respiratory status. Sport Mont, IV(10-11), 345-348.

Maksimović, N., \& Milošević, Z. (2006). Strategic approaches to changes of environment of sports organizations. Sport Mont, IV(10-11), 538-544.

Marčićević, Z. (2006). Bežični pristup internetu za potrebe sporta. Sport Mont, IV(10-11), 167-172.

Martinović, D. (2006). Relationship between accomplishment and morphological characteristics of students in teaching physical education. Sport Mont, IV(10-11), 272-275.

Martinović, D., \& Branković, D. (2006). Mountain bicycle - as means for realising tracking tours. Sport Mont, IV(10-11), 307-314.

Marušić, R. (2006). Handball as elective sport in the third round of the nine years primary school. Sport Mont, IV(1011), 694-698.

Marušić, R., \& Petković, J. (2006). Gimnastic jumps - over and their connection with motoric abilities of the fifth grade students. Sport Mont, IV(10-11), 237-242.

Mavrić, F. (2006). Program stretching-a za potrebe treninga rukometaša. Sport Mont, IV(10-11), 216-222.

Mavrić, F. (2006). Uticaj antropometrijskih karakteristika i funkcionalnih sposobnosti na bočnu i dubinsku pokretljivost rukometaša. Sport Mont, IV(10-11), 256-260.

Međedović, E. (2006). Mišljenja i stavovi razrednih učitelja prema vrednovanju (evaluaciji) i ocenjivanju u nastavi fizičkog vaspitanja. Sport Mont, IV(10-11), 590-598.

Međedović, E., \& Međedović, A. (2006). Integrativni pristup nastavi u prirodi kao savremenoj pedagoškoj inicijativi (empirijsko istraživanje sa osvrtom na fizičko vaspitanje). Sport Mont, IV(10-11), 575-582.

Mekić, H., \& Petković, E. (2006). Uticaj prediktorskog sistema varijabli antropološkog statusa na uspešnost prve etape bazične selekcije u sportskoj gimnastici kod devojčica. Sport Mont, IV(10-11), 400-405.

Mekić, M. (2006). Pathologic cognitive factors of boys from high school after war period. Sport Mont, IV(10-11), 209215.

Mekić, M., \& Hadžić, R. (2006). Base movement influence of hitting ball using had and foot in football game. Sport Mont, IV(10-11), 160-166.

Mijatović, S. (2006). Initiatives and suggestions for introduction of gymnastics in elementary schools of the principality of serbia (elementary schools, gymnastics, initiatives, suggestions, introduction. Sport Mont, IV(10-11), 472-477.

Mikalački, M., \& Čokorilo, N. (2006). Uloga tai či čuana u očuvanju zdravlja, sprečavanja i lečenja bolesti. Sport Mont, IV(10-11), 478-481.

Milojković, B., \& Dopsaj, M. (2006). Orienteering situation tests in the function of predicting success of police officers in topography field training. Sport Mont, IV(10-11), 248255.

Milošević, B. (2006). Sport journalism and professional ethics: identity problem. Sport Mont, IV(10-11), 627-633.

Milosević, D. (2006). The estimation of the circled form of performance influence on the development of the speed in the physical education teaching. Sport Mont, IV(10-11), 285292.

Milošević, D. (2006). The importance and the role of the polygon in the development obiomotoring experiences of the first series of nine years lasted elementary school students. Sport Mont, IV(10-11), 413-421.
Mirvić, E. (2006). Relacije motoričkih i sitaciono-motoričkih sposobnosti u košarkaškoj igri. Sport Mont, IV(10-11), 7479.

Mirvić, E. (2006). Uticaj konativnih karakteristika na rezultatsku uspješnost u nekim sportskim igrama kod učenica srednje škole. Sport Mont, IV(10-11), 223-228.

Mladenović, I., \& Nikolić, M. (2006). Difference in anthropometric characteristics and funkctional abilities active and non active women. Sport Mont, IV(10-11), 671-674

Mladenović, I., \& Nikolić, M. (2006). Difference in state of nutrition between active and non active women. Sport Mont, IV(10-11), 665-670.

Nemec, P. (2006). The application of eks test in sporting practice. Sport Mont, IV(10-11), 71-73.

Nešić, M. (2006). Motivational determinants of managers in karate. Sport Mont, IV(10-11), 523-530.

Nićin, D. (2006). Coach - explorer - manager. Sport Mont, IV (10-11), 446-452.

Nikolić, B. (2006). The influence of the morphological characteristics on the precision of thrownig the ball into the basket among the players aged between tweelve and fourteen. Sport Mont, IV(10-11), 428-432.

Nikolić, I. (2006). Spa and climatic resorts (centers) as resources of program of sport recreation implementation. Sport Mont, IV(10-11), 502-509.

Nikolić, I. (2006). Viewpoints of examinee towards the use of program of sport recreation in tourism. Sport Mont, IV(1011), 569-574.

Obadov, S. (2006). Effects of the specific motor exercises on the basic motor status of judokas. Sport Mont, IV(10-11), 229-236.

Obadov, S. (2006). Structural analysis of conditional preparation in judo. Sport Mont, IV(10-11), 321-326.

Opavsky, P. (2006). Validnost testova skočnosti. Sport Mont, IV (10-11), 17-20.

Petković, J. (2006). Connection of turn ahead and turn back with motoric abilities of the fifth grade students. Sport Mont, IV(10-11), 120-125.

Plojović, S. (2006). Application of information technology in sport. Sport Mont, IV(10-11), 482-487.

Plojović, S. (2006). Informational approach on training process. Sport Mont, IV(10-11), 622-626.

Popović, L. M., \& Mirić, D. (2006). Effect of physical exercise on lipid peroxidation and antioxidant ascorbic acid defense. Sport Mont, IV(10-11), 42-48.

Radoš, J. (2006). The philosophy of education and sport. Sport Mont, IV(10-11), 516-522.

Radović, M. (2006). Fundraising in sport. Sport Mont, IV(1011), 599-606.

Radović, M. (2006). Methods of organizing in endurance and prognosis of results in wrestling of greek-rome style. Sport Mont, IV(10-11), 675-679.

Radović, M. (2006). Self-defense with the teaching methods of performance. Sport Mont, IV(10-11), 381-386.

Radulović, B., \& Goranović, K. (2006). Comparable analysis of training operators qualities among swimmers of Montenegro and Vojvodina. Sport Mont, IV(10-11), 422-427.

Raičković, N. (2006). The importance of physical ability and technical preparation for the growth of young footballers. Sport Mont, IV(10-11), 644-650.

Rašović, D. (2006). Start to play tennis like incetive to development sports in Montenegro. Sport Mont, IV(10-11), 686693.

Razanica, F. (2006). Uticaj motoričkih sposobnosti i konativnih regulativnih mehanizama na situaciono-motoričke sposob- 
nosti u košarci. Sport Mont, IV(10-11), 155-159.

Ražanica, F. (2006). Uticaj motoričkih sposobnosti i konativnih regulativnih mehanizama na rezultatsku uspješnost u sportskim igrama. Sport Mont, IV(10-11), 95-100.

Šabotić, B. (2006). Natural ways of moving as basis of motorical development with kindergarten children. Sport Mont, IV (10-11), 387-394.

Šabotić, B. (2006). Predictorical values of basic - motorical abilities and relations of motorical informations in volleyball at 15 year old pupils. Sport Mont, IV(10-11), 375380.

Šekeljić, G., \& Stamatović, M. (2006). Instrument for evaluation of the adapted abilities from the element of basketball technique. Sport Mont, IV(10-11), 261-271.

Šekeljić, G., \& Stamatović, M. (2006). Reforms of physical education - between essence and existence. Sport Mont, IV(10-11), 556-568.

Šiljak, V. (2006). Management of the sport event ,the mini olympic games - Zemun 2004.“. Sport Mont, IV(10-11), 545-550.

Stefanović, R. (2006). The influence of cross-training due to spa treatment in curring functional neurotic disorders. Sport Mont, IV(10-11), 36-41.

Stefanović, R. (2006). The influence of experimental work on improving the speed endurance at students' of faculty of physical culture in Leposavić. Sport Mont, IV(10-11), 136143.

Stojiljković, S., \& Branković, N. (2006). Dynamic strength development using "station-based" workouts. Sport Mont, IV (10-11), 349-353.

Tomislav, O., \& Madić, D. (2006). The influence of nutritients in swimmers eating. Sport Mont, IV(10-11), 531-537.

Vučković, G. (2006). Influence of basic in shooting training realized according to international standards on the efficiency of a gun used by policewomen. Sport Mont, IV(10-11), 327333.

Vučković, I. (2006). Tip organizacije grupe u košarkaškim timovima 1. lige Srbije i Crne Gore. Sport Mont, IV(10-11), 551-555.

Živanović, N., \& Kafedzić, E. (2006). Sport u 21. veku. Sport Mont, IV(10-11), 27-35.

Zrnzević, N. (2006). The differences in morphological characteristics and motor abilities male and female students of the second grade of primary school. Sport Mont, IV(10-11), 488-494.

Zrnzević, N. (2006). The realization of the programme contents for physical education in the second grade of primary school based on minimal requirements. Sport Mont, IV(1011), 495-501.

\section{Vukotic}

University of Montenegro, Faculty for Sport and Physical Education, Narodne omladine bb, 81400 Niksic, Montenegro

e-mail:marinavukotic@yahoo.com 
